\title{
Penggunaan Asam Lemak Omega-3 sebagai Terapi Pendukung dalam Perawatan Periodontitis
}

\author{
Pingkan A. Lengkong, Johanna A. Khoman, Pritartha S. Anindita
}

\author{
Program Studi Pendidikan Dokter Gigi Fakultas Kedokteran Universitas Sam Ratulangi, \\ Manado, Indonesia \\ Email: angellinapingkan@gmail.com
}

\begin{abstract}
Periodontitis is an inflammation of periodontal tissue characterized by clinical attachment loss, periodontal pocket formation, gingival recession, and periodontal tissue destruction. Periodontitis can be treated by surgical or non-surgical methods. One of the nonsurgical methods is host modulation therapy which can reduce the damage by treating the chronic inflammatory response. Host modulation therapy is in the form of drugs or supplements that have anti-inflammatory properties. Omega-3 fatty acids have anti-inflammatory properties that serve as a protection against inflammation and infection including periodontitis. This study was aimed to obtain the effect of using omega-3 fatty acids as supportive therapy in the treatment of periodontitis. This was a literature review study by using PubMed, Clinical Key and Google Scholar databases. The keywords used were omega-3 fatty acids and periodontitis. After being selected based on inclusion and exclusion criteria, a critical appraisal was carried out to obtain seven randomized control trial literature. The results showed that the use of omega- 3 fatty acids had an effect on the mean value of decreasing probing pocket depth and increasing clinical attachment of periodontal tissues. In conclusion, omega-3 fatty acids have an effect and can be used as a supportive therapy in the treatment of periodontitis. Omega- 3 fatty acids lead to a better increase in the resolution of inflammation and can accelerate the healing of periodontal tissues by decreasing probing pocket depth and increasing clinical attachment.
\end{abstract}

Keywords: omega-3 fatty acids; periodontal tissue; periodontitis

\begin{abstract}
Abstrak: Periodontitis adalah inflamasi jaringan periodontal yang ditandai dengan kehilangan perlekatan klinis, pembentukan saku periodontal, resesi gingiva, dan kerusakan jaringan peridontal. Periodontitis dapat diobati dengan metode bedah maupun non bedah. Salah satu metode non bedah yaitu terapi modulasi host yang dapat mengurangi kerusakan dengan mengobati aspek respons inflamasi kronis. Terapi modulasi host berupa pemberian obat maupun suplemen yang memiliki sifat anti inflamasi. Asam lemak omega-3 memiliki sifat anti inflamasi yang berfungsi sebagai perlindungan dalam melawan peradangan dan infeksi termasuk periodontitis. Penelitian ini bertujuan untuk mengetahui gambaran pengaruh penggunaan asam lemak omega-3 sebagai terapi pendukung dalam perawatan periodontitis. Jenis penelitian ialah suatu literature review menggunakan database PubMed, Clinical Key. dan Google Scholar. Kata kunci yang digunakan yaitu omega-3 fatty acids and periodontitis. Setelah diseleksi berdasarkan kriteria inklusi dan eksklusi, dilakukan critical appraisal dan didapatkan tujuh literatur randomized control trial. Hasil penelitian mendapatkan bahwa penggunaan asam lemak omega-3 memengaruhi nilai rerata penurunan kedalaman probing poket dan meningkatkan perlekatan klinis jaringan periodontal. Simpulan penelitian ini ialah asam lemak omega-3 memiliki pengaruh dan dapat digunakan sebagai terapi pendukung dalam perawatan periodontitis. Asam lemak omega-3 menyebabkan peningkatan yang lebih baik dalam resolusi peradangan dan dapat mempercepat penyembuhan jaringan periodontal dilihat dari penurunan kedalaman probing poket dan meningkatnya perlekatan klinis.
\end{abstract}

Kata kunci: asam lemak omega-3; jaringan periodontal; periodontitis 


\section{PENDAHULUAN}

Jaringan periodontal adalah jaringan pendukung yang mengelilingi gigi, terdiri dari gingiva, tulang alveolar, sementum, dan ligamen periodontal. Jaringan ini dikatakan sehat jika secara klinis tidak terlihat adanya kehilangan perlekatan dan inflamasi. ${ }^{1}$

Periodontitis adalah inflamasi jaringan periodontal yang ditandai dengan kehilangan perlekatan klinis, pembentukan saku periodontal, resesi gingiva, dan kerusakan jaringan peridontal. $^{2,3}$ Menurut Global Burden of Disease Study tahun 2016, prevalensi penyakit periodontal di dunia sebesar $25,9 \%$ sedangkan di Indonesia prevalensi periodontitis sebesar $73,1-75,0 \% .^{4,5}$

Periodontitis dapat diobati dengan metode bedah dan non bedah. Perawatan periodontitis dengan tindakan bedah memiliki keberhasilan yang tinggi namun berisiko terutama untuk pasien dengan riwayat penyakit sistemik. $^{6}$

Metode non bedah yang paling sering digunakan saat ini yaitu scaling dan root planing untuk menghilangkan karang gigi dan debris serta bakteri yang menempel pada gigi. Scaling dan root planing kadang tidak maksimal misalnya pada pasien dengan status kebersihan mulut yang buruk, atau pada pasien penyandang diabetes. Oleh sebab itu diperlukan terapi tambahan berupa pemberian obat anti mikroba dan anti inflamasi untuk meningkatkan hasil perawatan. ${ }^{7}$

Salah satu pilihan dalam perawatan non bedah yaitu terapi modulasi host (TMH) yang menghasilkan peningkatan stabilitas periodontal setelah perawatan periodontal konvensional seperti scaling dan root planing dan bahkan pembedahan. ${ }^{8-10}$

Terapi modulator host (TMH) berupa pemberian obat-obatan seperti obat anti inflamasi baik secara sistemik maupun lokal misalnya obat anti inflamasi nonsteroid, tetrasiklin, dan bifosfonat. Obat-obat tersebut berperan untuk meredakan rasa sakit dan mencegah perluasan inflamasi, namun obat ini memiliki keterbatasan dan efek samping seperti ulkus peptik dengan prevalensi 15$35 \% .^{11-13}$ Penggunaan obat anti inflamasi juga dapat menyebabkan lesi gastrointestinal dengan prevalensi antara 10-20\%. ${ }^{14}$
Karena adanya efek samping yang ditimbulkan akibat penggunaan obat anti inflamasi jangka panjang maka perlu dicari alternatif bahan yang lebih aman, antara lain asam lemak omega-3 yang merupakan bahan alami yang dapat ditemukan pada organisme laut, kacang-kacangan, atau bijibijian. $^{15}$

Asam lemak omega-3 memiliki nilai terapeutik, anti inflamasi, dan tindakan perlindungan pada berbagai penyakit termasuk periodontitis. ${ }^{16}$ Pengaplikasian asam lemak omega-3 dapat memberikan pelindungan lebih terhadap jaringan yang mengalami inflamasi dan kehilangan tulang alveolar yang diakibatkan oleh periodontitis. ${ }^{17}$ Beberapa penelitian menyatakan asam lemak omega-3 menyebabkan perbaikan yang bermakna pada kondisi periodontal serta pengendalian diabetes dimana rejimen yang diteliti menghasilkan produksi resolvin dan dokosatrien. Senyawa ini memiliki anti inflamasi dan pengaturan imun yang kuat. ${ }^{9}$ Studi yang dilakukan oleh beberapa peneliti menyoroti sifat anti inflamasi asam lemak omega-3 menyatakan senyawa ini memiliki aktivitas anti bakteri yang kuat terhadap berbagai patogen oral. ${ }^{18}$

Berdasarkan latar belakang tersebut, penulis tertarik melakukan studi pustaka untuk membahas dan menelaah berbagai informasi ilmiah mengenai penggunaan asam lemak omega-3 sebagai terapi pendukung dalam perawatan periodontitis.

\section{METODE PENELITIAN}

Penelitian ini dilaksanakan pada bulan April-Juni 2021. Jenis penelitian ialah suatu literature review dan data yang digunakan diperoleh melalui database berupa Pubmed, Clinical Key, dan Google Scholar. Pada penelitian ini, artikel yang telah memenuhi kriteria inklusi dan ekslusi serta kelayakan telah teruji berjumlah tujuh artikel.

\section{HASIL PENELITIAN}

Tujuh artikel melalui proses reduksi data sesuai kriteria inklusi dan eksklusi serta analisis data melalui the Joanna Briggs Institute (JBI) critical appraisal. Seluruh artikel menggunakan metode studi eksperi- 
mental yakni randomized control trial.

Tabel 1 memperlihatkan karakteristik ketujuh artikel yang digunakan dalam penelitian ini serta rangkuman hasil.

Tabel 2 memperlihatkan bahwa keseluruhan artikel berasal dari luar negeri dan populasi dalam penelitian ini berkisar antara 21-90 pasien. Terapi yang digunakan pada tujuh artikel yaitu scaling dan root planing dengan tambahan suplementasi asam lemak omega-3. Lama penelitian yaitu antara 12 minggu sampai 6 bulan.

Tabel 3 memperlihatkan distribusi pengaruh penggunaan asam lemak omega-3 pada tingkat perlekatan klinis jaringan periodontal pasien dengan periodontitis.

Tabel 4 memperlihatkan distribusi pengaruh penggunaan asam lemak omega-3 pada kedalaman poket periodontal pasien dengan periodontitis.

Tabel 1. Karakteristik artikel dan rangkuman hasil

\begin{tabular}{|c|c|c|c|c|c|}
\hline $\begin{array}{c}\text { Peneliti dan } \\
\text { Tahun }\end{array}$ & Lokasi & Populasi & Terapi & $\begin{array}{l}\text { Desain } \\
\text { Metode }\end{array}$ & Hasil \\
\hline $\begin{array}{l}\text { Stańdo et al, } \\
2020^{19}\end{array}$ & Polandia & 30 & $\begin{array}{l}\text { SRP dan } \\
\text { asam lemak } \\
\text { omega } 3\end{array}$ & $\begin{array}{l}\text { Randomized } \\
\text { controlled } \\
\text { trial }\end{array}$ & $\begin{array}{l}\text { Terapi tambahan asam lemak } \\
\text { omega-3 menunjukkan pe- } \\
\text { ningkatan perlekatan klinis } \\
\text { yang lebih tinggi. }\end{array}$ \\
\hline $\begin{array}{l}\text { Kujur et al, } \\
2020^{8}\end{array}$ & India & 90 & $\begin{array}{l}\text { SRP dan } \\
\text { asam lemak } \\
\text { omega } 3\end{array}$ & $\begin{array}{l}\text { Randomized } \\
\text { controlled } \\
\text { trial }\end{array}$ & $\begin{array}{l}\text { Menunjukkan penurunan ke- } \\
\text { dalaman probing poket dan } \\
\text { peningkatan perlekatan klinis } \\
\text { yang lebih baik. }\end{array}$ \\
\hline $\begin{array}{l}\text { Umrania et al, } \\
2017^{22}\end{array}$ & India & 40 & $\begin{array}{l}\text { SRP dan } \\
\text { asam lemak } \\
\text { omega } 3\end{array}$ & $\begin{array}{l}\text { Randomized } \\
\text { controlled } \\
\text { trial }\end{array}$ & $\begin{array}{l}\text { Pengukuran kedalaman poket } \\
\text { dan perlekatan klinis setelah } \\
\text { perawatan dengan asam lemak } \\
\text { omega-3 tidak menunjukkan } \\
\text { perubahan yang signifikan. }\end{array}$ \\
\hline $\begin{array}{l}\text { Deore et al, } \\
2014^{11}\end{array}$ & India & 60 & $\begin{array}{l}\text { SRP dan } \\
\text { asam lemak } \\
\text { omega } 3\end{array}$ & $\begin{array}{l}\text { Randomized } \\
\text { controlled } \\
\text { trial }\end{array}$ & $\begin{array}{l}\text { Pemberian asam lemak ome- } \\
\text { ga-3 setiap hari secara ber- } \\
\text { makna menurunkan kedalam- } \\
\text { an poket, dan meningkatkan } \\
\text { level perlekatan. }\end{array}$ \\
\hline $\begin{array}{l}\text { Elgendy dan } \\
\text { Kazem, } 2018^{20}\end{array}$ & Mesir & 50 & $\begin{array}{l}\text { SRP dan } \\
\text { asam lemak } \\
\text { omega } 3\end{array}$ & $\begin{array}{l}\text { Randomized } \\
\text { controlled } \\
\text { trial }\end{array}$ & $\begin{array}{l}\text { Suplemen asam lemak omega- } \\
3 \text { tambahan mengurangi pera- } \\
\text { dangan periodontal yaitu pe- } \\
\text { ngurangan kedalaman poket } \\
\text { dan peningkatan perlekatan } \\
\text { klinis. }\end{array}$ \\
\hline $\begin{array}{l}\text { Martinez et al, } \\
2014^{21}\end{array}$ & Brazil & 21 & $\begin{array}{l}\text { SRP dan } \\
\text { asam lemak } \\
\text { omega } 3\end{array}$ & $\begin{array}{l}\text { Randomized } \\
\text { controlled } \\
\text { trial }\end{array}$ & $\begin{array}{l}\text { Parameter klinis periodontal } \\
\text { yaitu kedalaman probing dan } \\
\text { perlekatan klinis tidak berbeda } \\
\text { secara bermakna antara ke- } \\
\text { lompok uji dan plasebo }\end{array}$ \\
\hline $\begin{array}{l}\text { Keskiner et al, } \\
2017^{23}\end{array}$ & Turki & 30 & $\begin{array}{l}\text { SRP dan } \\
\text { asam lemak } \\
\text { Omega } 3\end{array}$ & $\begin{array}{l}\text { Randomized } \\
\text { controlled } \\
\text { trial }\end{array}$ & $\begin{array}{l}\text { Kedalaman probing poket dan } \\
\text { pengurangan kehilangan per- } \\
\text { lekatan klinis menunjukkan } \\
\text { peningkatan bermakna diban- } \\
\text { dingkan pengukuran awal, } \\
\text { tetapi tidak ada perbedaan } \\
\text { dengan kelompok kontrol }\end{array}$ \\
\hline
\end{tabular}


Tabel 2. Distribusi lokasi, populasi, terapi dan lama penelitian

\begin{tabular}{|c|c|c|c|c|}
\hline Peneliti & Lokasi & Populasi & Terapi & Lama Penelitian \\
\hline Stańdo et al ${ }^{19}$ & Polandia & 30 & $\begin{array}{l}\text { SRP dan asam lemak } \\
\text { omega-3 }\end{array}$ & 3 bulan \\
\hline Kujur et $\mathrm{al}^{8}$ & India & 90 & $\begin{array}{c}\text { SRP dan asam lemak } \\
\text { omega-3 }\end{array}$ & 3 bulan \\
\hline 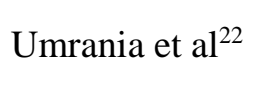 & India & 40 & $\begin{array}{c}\text { SRP dan asam lemak } \\
\text { omega-3 }\end{array}$ & 3 bulan \\
\hline Deore et al $^{11}$ & India & 60 & $\begin{array}{c}\text { SRP dan asam lemak } \\
\text { omega-3 }\end{array}$ & 12 minggu \\
\hline $\begin{array}{l}\text { Elgendy dan } \\
\text { Kazem }^{20}\end{array}$ & Mesir & 50 & $\begin{array}{c}\text { SRP dan asam lemak } \\
\text { omega-3 }\end{array}$ & 6 bulan \\
\hline Martinez et $\mathrm{al}^{21}$ & Brazil & 21 & $\begin{array}{c}\text { SRP dan asam lemak } \\
\text { omega-3 }\end{array}$ & 4 bulan \\
\hline Keskiner et $\mathrm{al}^{23}$ & Turki & 30 & $\begin{array}{c}\text { SRP dan asam lemak } \\
\text { omega-3 }\end{array}$ & 6 bulan \\
\hline
\end{tabular}

SRP: scaling and root planing

Tabel 3. Gambaran pengaruh penggunaan asam lemak omega-3 pada tingkat perlekatan klinis jaringan periodontal pasien dengan periodontitis

\begin{tabular}{|c|c|c|c|c|c|c|}
\hline \multirow[b]{2}{*}{ Peneliti } & \multirow[b]{2}{*}{ Populasi } & \multirow[b]{2}{*}{ CAL } & \multicolumn{4}{|c|}{ Kehilangan Perlekatan Klinis } \\
\hline & & & $\begin{array}{l}\text { Baseline } \\
\mathrm{n}(\text { Mean })^{*}\end{array}$ & $\begin{array}{c}3 \text { Bulan } \\
\text { n(Mean })^{*}\end{array}$ & $\begin{array}{l}4 \text { Bulan } \\
\text { n(Mean)* }\end{array}$ & $\begin{array}{c}6 \text { Bulan } \\
\text { n(Mean) }\end{array}$ \\
\hline Stańdo et a ${ }^{19}$ & 30 & $\geq 5 \mathrm{~mm}$ & $16(5,8)$ & $16(4,4)$ & - & - \\
\hline Kujur et al ${ }^{8}$ & 90 & $3-5 \mathrm{~mm}$ & $40(4,78)$ & $40(1,0)$ & - & - \\
\hline Umrania et al ${ }^{22}$ & 40 & $\geq 5 \mathrm{~mm}$ & $20(3,78)$ & $20(3.36)$ & - & - \\
\hline Deore et al ${ }^{11}$ & 60 & 4-6 mm & $30(5,53)$ & $30(2,73)$ & - & - \\
\hline $\begin{array}{l}\text { Elgendy dan } \\
\text { Kazem }^{20}\end{array}$ & 50 & $\geq 5 \mathrm{~mm}$ & $25(5,96)$ & $25(3,58)$ & - & $25(3,40)$ \\
\hline Martinez et $\mathrm{al}^{21}$ & 21 & $\geq 5 \mathrm{~mm}$ & $10(11,0)$ & - & $10(6.0)$ & - \\
\hline Keskiner et $\mathrm{al}^{23}$ & 30 & $\geq 6 \mathrm{~mm}$ & $15(4,59)$ & $15(3,50)$ & - & $15(3,53)$ \\
\hline
\end{tabular}

CAL: Clinical Attachment Loss; * Jumlah sampel kelompok uji dengan tambahan asam lemak omega-3

Tabel 4. Gambaran penggunaan asam lemak omega-3 pada kedalaman poket periodontal pasien dengan periodontitis

\begin{tabular}{|c|c|c|c|c|c|c|}
\hline \multirow{3}{*}{ Peneliti } & \multirow{3}{*}{ Populasi } & \multirow{3}{*}{ PPD } & \multicolumn{4}{|c|}{ Kedalaman Poket } \\
\hline & & & Baseline & 3 Bulan & 4 Bulan & 6 Bulan \\
\hline & & & $\mathrm{n}(\text { Mean })^{*}$ & $\mathrm{n}(\text { Mean })^{*}$ & $\mathrm{n}(\text { Mean })^{*}$ & $\mathrm{n}(\text { Mean })^{*}$ \\
\hline Stańdo et al ${ }^{19}$ & 30 & $\geq 4 \mathrm{~mm}$ & $16(5,0)$ & $16(3,7)$ & - & - \\
\hline Kujur et $\mathrm{al}^{8}$ & 90 & $3-5 \mathrm{~mm}$ & $40(3,77)$ & $40(1,0)$ & - & - \\
\hline Umrania et $\mathrm{al}^{22}$ & 40 & $\geq 3 \mathrm{~mm}$ & $20(3,87)$ & $20(3,53)$ & - & - \\
\hline Deore et $\mathrm{al}^{11}$ & 60 & $\geq 5 \mathrm{~mm}$ & $30(4.26)$ & $30(2,15)$ & - & - \\
\hline $\begin{array}{c}\text { Elgendy dan } \\
\text { Kazem }^{20}\end{array}$ & 50 & $\geq 5 \mathrm{~mm}$ & $25(6,00)$ & $25(3,70)$ & - & $25(3,40)$ \\
\hline Martinez et $\mathrm{al}^{21}$ & 21 & $\geq 6 \mathrm{~mm}$ & $10(4,6)$ & - & $10(0,5)$ & - \\
\hline Keskiner et $\mathrm{al}^{23}$ & 30 & $\geq 7 \mathrm{~mm}$ & $15(3,72)$ & $15(2,56)$ & - & $15(2,46)$ \\
\hline
\end{tabular}

PPD: Periodontal Pocket Depth; * Jumlah sampel kelompok uji dengan tambahan asam lemak omega-3 


\section{BAHASAN}

Penelitian Kujur et $\mathrm{al}^{8}$ bertujuan untuk mengevaluasi dan membandingkan kemanjuran klinis asam lemak omega-3 sebagai tambahan setelah scaling dan root planing dalam pengobatan periodontitis. Hasil penelitian menunjukkan adanya peningkatan bermakna pada 1 dan 3 bulan dalam tingkat perlekatan klinis dan penurunan kedalaman probing pada pasien dengan penggunaan terapi asam lemak omega-3.

Stańdo et al $^{19}$ dalam penelitiannya terhadap 30 orang menunjukkan bahwa suplementasi dengan asam lemak omega-3 memiliki keunggulan regenerasi jaringan pada pasien dengan periodontitis. Kedalaman poket berkurang setelah tiga bulan dan peningkatan bermakna secara statistik dari nilai rerata perlekatan klinis dibandingkan sebelum perawatan. Tidak ada efek samping yang tercatat dalam pemeriksaan jaringan lunak dan keras mulut selama pengobatan asam lemak omega-3.

Deore et $\mathrm{al}^{11}$ melaporkan penurunan kedalaman probing poket pada 6 dan 12 minggu $(\mathrm{p}<0,001)$. Perlekatan klinis hanya menunjukkan peningkatan pada 12 minggu ( $<<0,001$ ). Sekitar $20 \%$ pada kelompok uji dengan asam lemak omega-3 menunjukkan perlekatan klinis yang lebih baik dibanding kelompok tanpa tambahan asam lemak omega-3.

Penelitian Elgendy dan Kazem ${ }^{20}$ membuktikan bahwa terdapat penurunan pada kedalaman poket dan kehilangan perlekatan klinis yang bermakna di semua periode evaluasi pada 3 dan 6 bulan dibandingkan dengan nilai awal sebelum perawatan.

Berbeda dari penelitian sebelumnya, penelitian klinis oleh Martinez et $\mathrm{al}^{21}$ menyimpulkan bahwa suplementasi makanan asam lemak omega-3 tidak berpengaruh pada hasil klinis pengobatan periodontitis. Hasil ini dapat dikaitkan dengan ukuran sampel yang kecil (21 pasien).

Hasil penelitian Umrania et $\mathrm{al}^{22}$ menyimpulkan bahwa suplementasi asam lemak omega-3 dapat mengurangi peradangan dengan cara memodulasi profil sitokin. Terapi asam lemak omega-3 tidak tercermin pada hasil klinis pemeriksaan kedalaman probing poket dan perlekatan klinis dikarenakan sebagian besar pasien menjalani diet vegetarian dan nonvegetarian yang tidak mengonsumsi ikan.

Keskiner et $\mathrm{al}^{23}$ menyatakan bahwa tidak terdapat efek positif asam lemak omega-3 pada parameter klinis dikarenakan efeknya terlalu kecil untuk dideteksi dengan ukuran sampel yang digunakan (30 pasien).

Dari tujuh artikel tersebut, terdapat empat artikel yang menyatakan penggunaan asam lemak omega-3 berpengaruh terhadap perbaikan klinis yang dibuktikan dengan pengurangan kedalaman poket dan peningkatan perlekatan klinis jaringan periodontal, sedangkan tiga artikel lainnya tidak menunjukkan pengaruh pada keadaan klinis jaringan periodontal dikarenakan ukuran sampel yang kecil.

Pengaruh penggunaan asam lemak omega-3 dalam perawatan periodontitis dapat dipengaruhi oleh beberapa fraktor yaitu; konsumsi makanan, kepatuhan dalam penggunaan suplemen asam lemak omega3, dan kepatuhan dalam menjaga kebersihan gigi dan mulut setiap hari.

Keseluruhan jurnal menyatakan bahwa pasien diminta untuk mengisi buku harian diet yang mendokumentasikan konsumsi harian minyak ikan dan keluhan tentang konsumsinya. Selanjutnya, untuk memastikan pasien menjaga kebersihan mulutnya, dilakukan evaluasi setiap 3-4 minggu dari awal perawatan dilakukan.

Penggunaan asam lemak omega-3 sebagai terapi pendukung dapat berpengaruh pada peningkatan proses penyembuhan jaringan periodontal khususnya pada pasien dengan periodontitis. Hal ini dipengaruhi oleh efek anti inflamasi yang dimiliki asam lemak omega-3. ${ }^{24}$

Kerusakan jaringan pada periodontal dapat terjadi karena interaksi antara bakteri plak gigi dan respon inflamasi imun, yang diinduksi oleh mediator seperti metabolit asam arakidonat (AA), sitokin, dan enzim. Asam lemak omega-3 yaitu eicosapentaenoic acid (EPA) dan docosahexaenoic acid (DHA) dapat menghambat metabolisme asam amino menjadi eikosanoid inflamasi dan sitokin. ${ }^{11,25}$ 
Baik EPA dan DHA dapat menurunkan produksi tumour necrosis factor-alpha (TNF- $\alpha$ ), interleukin-1 $\beta$ (IL-1 $\beta$ ), dan IL-6 sebagai respons terhadap lipopolisakarida, selain itu meningkatkan anti inflamasi sitokin IL-10. EPA dan DHA juga ditemukan dapat menurunkan ekspresi molekul adhesi pada makrofag dan limfosit, oleh karena itu dapat mengurangi adhesi antara sel inflamasi dan sel endotel. ${ }^{26}$

Asam lemak omega-3 juga dapat menghasilkan produksi pro-resolusi yaitu resolvin dan protektin yang berfungsi sebagai mediator inflamasi. Senyawa ini memiliki efek anti-inflamasi dan pengaturan kekebalan yang kuat dengan menghambat produksi superoksida, kemotaksis dan neutrophil, juga dapat mengurangi produksi enzim dan sitokin pro inflamasi, sehingga mengurangi peradangan periodontal dan tulang keropos. $^{27,28}$

Keterbatasan penelitian ini ialah jumlah sampel penelitian kecil dan durasi pengamatan singkat sehingga perubahan parameter setelah penelitian tidak dapat diperiksa dan jumlah literatur sedikit.

\section{SIMPULAN}

Asam lemak omega-3 memiliki pengaruh dan dapat digunakan sebagai terapi pendukung dalam perawatan periodontitis karena efek anti inflamasinya. Penggunaan asam lemak omega-3 pada perawatan periodontitis dapat berpengaruh dalam mengurangi kedalaman poket dan meningkatkan perlekatan klinis jaringan periodontal.

\section{Konflik Kepentingan}

Penulis menyatakan tidak terdapat konflik kepentingan dalam studi ini.

\section{DAFTAR PUSTAKA}

1.Saputri D. Gambaran radiograf pada penyakit periodontal. J Syiah Kuala Dent Soc. 2018;1(3):16-21.

2.Yucel-Lindberg T, Båge T. Inflammatory mediators in the pathogenesis of periodontitis. Expert Rev Mol Med [Internet]. 2013/08/05. 2013;15:e7. Available from: https://www. cambridge.org/core/article/inflammator $\mathrm{y}$-mediators-in-the-pathogenesis-ofperiodontitis/05B60424BB7C7B94650 0A924A8B53453

3.Michaud DS, Fu Z, Shi J, Chung M. Periodontal disease, tooth loss, and cancer risk. Epidemiol Rev. 2017;39(1):49-58.

4.Vos T, Abajobir AA, Abbafati C, Abbas KM, Abate KH, Abd-Allah F, et al. Global, regional, and national incidence, prevalence, and years lived with disability for 328 diseases and injuries for 195 countries, 1990-2016: A systematic analysis for the Global Burden of Disease Study 2016. Lancet. 2017; 390(10100):1211-59.

5.Kementerian Kesehatan RI BLK. Laporan_Nasional_RKD2018_FINAL.pdf

[Internet]. Badan Penelitian dan Pengembangan Kesehatan. 2018. p. 198. Available from: http://labdata. litbang.kemkes.go.id/images/download/ laporan/RKD/2018/Laporan_Nasional_ RKD2018_FINAL.pdf

6.Ika A. Efektivitas antara scaling root planing (Srp) dengan dan tanpa pemberian ciprofloxacin per oral pada penderita periodontitis. Insisiva Dent J. 2012;1(2): $70-81$.

7.Walters J, Lai P-C. Should antibiotics be prescribed to treat chronic periodontitis? Dent Clin North Am [Internet]. 2015/08/01. 2015 Oct:59(4):919-33. Available from: https://pubmed.ncbi. nlm.nih.gov/26427574

8.Kujur S, Goswami V, Nikunj A, Singh G, Bandhe S, Ghritlahre H. Efficacy of omega 3 fatty acid as an adjunct in the management of chronic periodontitis: A randomized controlled trial. Indian $\mathbf{J}$ Dent Res. 2020;31(2):229-35.

9.Elwakeel NM, Hazaa HH. Effect of omega 3 fatty acids plus low-dose aspirin on both clinical and biochemical profiles of patients with chronic periodontitis and type 2 diabetes: A randomized double blind placebo-controlled study. J Periodontal Res. 2015;50(6):721-9.

10.Emanuel M, Ying R. Host Modulation. In: Newman and Carranza's Clinical Periodontology [Internet]. (13th ed). Elsevier Inc.; 2021. p. 564-573.e5. Available from: https://doi.org/ 10.1016/B978-0-323-52300-4.00054-0

11.Deore GD, Gurav AN, Patil R, Shete AR, 
NaikTari RS, Inamdar SP. Omega 3 fatty acids as a host modulator in chronic periodontitis patients: A randomised, double-blind, palcebo-controlled, clinical trial. J Periodontal Implant Sci. 2014;44(1):25-32.

12.Yang M, Li L, Soh Y, Heo SM. Effects of omega-3 fatty acids and aspirin on Porphyromonas gingivalis-induced periodontitis in rats. J Periodontol. 2019; 90(11):1307-19.

13.Tenenbaum J. The epidemiology of nonsteroidal anti-inflammatory drugs. Can J Gastroenterol. 1999;13(2):119-22.

14.Soleha M, Isnawati A, Fitri N, Adelina R, Soblia HT, Winarsih W. Profil penggunaan obat antiinflamasi nonstreoid di Indonesia. J Kefarmasian Indones. 2018;8(2):109-17.

15.Sartika RAD. Pengaruh asam lemak jenuh, tidak jenuh dan asam lemak trans terhadap kesehatan. Kesmas Natl Public Heal J. 2008;2(4):154.

16.El-Sharkawy H, Aboelsaad N, Eliwa M, Darweesh M, Alshahat M, Kantarci A, et al. Adjunctive treatment of chronic periodontitis with daily dietary supplementation with omega-3 fatty acids and low-dose aspirin. J Periodontol. 2010; 81(11):1635-43.

17.Zare JA, Maghsoumi-Norouzabad L, Ashrafzadeh E, Yousefimanesh HA, Zakerkish M, Ahmadi AK, et al. Impact of cranberry juice enriched with omega-3 fatty acids adjunct with nonsurgical periodontal treatment on metabolic control and periodontal status in type 2 patients with diabetes with periodontal disease. J Am Coll Nutr [Internet]. 2018;37(1):71-9. Available from: https://doi.org/10.1080/07315724.2017. 1357509

18.Rampally P, Koduganti RR, Ganapathi SN, Panthula VR, Surya PJ. Comparison of effectiveness of low-dose aspirin versus omega-3 fatty acids as adjuvants to nonsurgical periodontal therapy in Type II diabetic patients with chronic periodontitis Introduction. J Indian Soc Periodontol. 2019;23(3):249-56.

19.Stańdo M, Piatek P, Namiecinska M, Lewkowicz P, Lewkowicz N. Omega-3 polyunsaturated fatty acids EPA and DHA as an adjunct to non-surgical treatment of periodontitis: A ran- domized clinical trial. Nutrients. 2020; 12(9):1-14.

20.Elgendy EA, Kazem HH. Effect of Omega-3 Fatty Acids on Chronic Periodontitis Patients in Postmenopausal Women: A Randomised Controlled Clinical Study. Oral Health Prev Dent [Internet]. 2018; 16(4):327-32. Available from: http://www.ncbi.nlm.nih.gov/pubmed/3 0175329

21.Martinez GL, Koury JC, Brito F, Fischer RG, Gustafsson A, Figueredo CM. The impact of non-surgical periodontal treatment on serum levels of long chainpolyunsaturated fatty acids: A pilot randomized clinical trial. J Periodontal Res. 2014;49(2):268-74.

22.Umrania VV, Deepika PCR, Kulkarni M. Evaluation of dietary supplementation of omega-3 polyunsaturated fatty acids as an adjunct to scaling and root planing on salivary interleukin- $1 \beta$ levels in patients with chronic periodontitis: A clinico-immunological study. J Indian Soc Periodontol.2018;21(5):113-8.

23.Keskiner I, Saygun I, Bal V, Serdar M, Dietary KA. Dietary supplementation with lowdose omega-3 fatty acids reduces salivary tumor necrosis factor- a levels in patients with chronic periodontitis: a randomized controlled clinical study. J Periodont Res.2017;52(4):695-703.

24.Naqvi A, Buettner C, Phillips R, Davis R, Mukamal K. Omega 3 fatty acids and periodontitis in U.S. adults. 2012; 110(11):1669-75.

25.Iwasaki M, Yoshihara A, Moynihan P, Watanabe R, Taylor GW, Miyazaki H. Longitudinal relationship between dietary $\omega-3$ fatty acids and periodontal disease. Nutrition [Internet]. 2010; 26(11-12):1105-9. Available from: http://dx.doi.org/10.1016/j.nut.2009.09. 010

26.Alhusseiny SM, El-Beshbishi SN. Omega polyunsaturated fatty acids and parasitic infections: An overview. Acta Trop [Internet]. 2020;207:105466. Available from: $\quad$ https://doi.org/10.1016/j. actatropica. 2020.105466

27.Serhan CN, Yacoubian S, Yang R. Anti-inflammatory and proresolving lipid mediators. Annu Rev Pathol [Internet]. 2008; 3(1):279-312. Available from: https:/ /pubmed.ncbi.nlm.nih.gov/18233953 
216 e-GiGi, Volume 9 Nomor 2, Juli-Desember 2021, hlm. 209-216

28.Hasturk H, Kantarci A, Ohira T, Arita M, Ebrahimi N, Chiang N, et al. RvE1 protects from local inflammation and

osteoclast- mediated bone destruction in periodontitis. FASEB J. 2006;20(2): 401-3. 